\section{EMBRYRIDDLE \\ Aeronautical University}

SCHOLARLY COMMONS
International Journal of Aviation, Aeronautics, and Aerospace

$1-31-2018$

\title{
Assessment and Comparison of Aviation Manufacturing Industries throughout Mexico and Brazil
}

\author{
Omar E. Morsi \\ Embry-Riddle Aeronautical University, morsio1@my.erau.edu \\ Kelly A. Whealan-George \\ Embry-Riddle Aeronautical University - Worldwide, georged8@erau.edu \\ Aaron D. Clevenger \\ bepress (DC Admins), cleve515@erau.edu
}

Follow this and additional works at: https://commons.erau.edu/ijaaa

Part of the Aviation and Space Education Commons, Industrial Engineering Commons, Industrial Technology Commons, International Trade Law Commons, Management and Operations Commons, Operational Research Commons, Other Aerospace Engineering Commons, Structures and Materials Commons, Technology and Innovation Commons, Tourism and Travel Commons, and the Transportation Law Commons

\section{Scholarly Commons Citation \\ Morsi, O. E., Whealan-George, K. A., \& Clevenger, A. D. (2018). Assessment and Comparison of Aviation Manufacturing Industries throughout Mexico and Brazil. International Journal of Aviation, Aeronautics, and Aerospace, 5(1). https://doi.org/10.15394/ijaaa.2018.1199}

This Literature Review is brought to you for free and open access by the Journals at Scholarly Commons. It has been accepted for inclusion in International Journal of Aviation, Aeronautics, and Aerospace by an authorized administrator of Scholarly Commons. For more information, please contact commons@erau.edu. 
Throughout the past ten years the aerospace sector has proven to be one of great importance and significant growth. As the overall demand for air travel soared, aircraft manufacturers have experienced increasing backlogs for new aircraft orders (Gates, 2016). Recent history has proven this trend's significance as air traffic figures have reportedly doubled every 15 years and have boasted an average annual growth rate of about $4.7 \%$ since 2013 (Taylor, 2015). These expectations of mushrooming traffic levels have been intensely influenced by macroeconomic variables such as local and international economic growth rates, consumer demand, trade, global population growth, and demographics. According to the Airbus Global Market Forecast prediction, the next 20 years should yield approximately 31,000 new passenger and freighter aircraft, valued around \$4.6 trillion (Taylor, 2015). Such demand for aircraft should lead to an overwhelming demand for aircraft financing across the globe. Expected demand has allowed for gradual regeneration of the international business sector, permitting a favorable outlook throughout the aviation industry.

A healthy development in aviation manufacturing throughout North America has explicitly emerged in Mexico, which is a new entrant nation in the aviation manufacturing industry (PwC, 2015). Within the past few years, Mexico has proven itself one of the most significant growth in aircraft manufacturing locations across the globe. It has begun to compete with nations like the United States and Canada while surpassing previous leading nations like China and Brazil. If current trends continue, Mexico might soon become the aircraft-manufacturing center of a new and emerging aviation sector.

\section{Manufacturing History in Brazil and Mexico}

In Brazil, aviation-manufacturing efforts have dated back to the early 1930s throughout the growth of Brazilian industrialization. For the first ten years, many civil and military initiatives flourished for manufacturing aircraft in series. These efforts were not only for companies that assembled aircraft but also those in the supply chain, except aircraft engines (Embraer S.A., 2012). The strategic need for an aeronautical industry in Brazil was identified during the military government from 1964-1985. By 1969, Brazil had constructed one of the most influential aircraft companies in the nation's history, Embraer. At the center of Brazilian pride, Embraer was privatized in 1994 and today is one of the largest aerospace companies across the globe (Lourencao, 2016). Embraer claims to create particular importance in helping bring the world closer together through the manufacturing of the most modern, versatile, and comfortable aircraft in its class (Embraer S.A., 2012). Today, Embraer is one of few aerospace manufacturing companies that operate in Brazil; 
however, others do exist including Aeromot, Avibrás, Helibras, and Sobraer, many of which are directly linked to Embraer (Utsumi, 2014).

Alternatively, Mexico has a rather young footprint in aviation manufacturing industries. A small group of select companies from the United States initiated the aviation industry 40 years ago by directing essential parts manufacturing and assembly tasks just south of the U.S. border into towns like Tijuana and Mexicali. However, it is only in the past ten years that Mexican aerospace manufacturing has begun to expand. The desirability of Mexican business overall is based on lower wage structures, significant political reform and Mexico's signing of the North American Free Trade Agreement (NAFTA). These features resulted in an environment for aerospace manufacturing industries to take flight. As a result, the business sector expanded rapidly throughout the past five years (Mecham, 2013). Today, many aviation-related companies like Bombardier, Cessna, Hawker-Beechcraft, General Electric, Honeywell and more have invested in the Mexican aerospace manufacturing market. Such investments resulted in a GDP growth rate of over $20 \%$ each year for the past five years as of 2014, totaling approximately MXN 1.9 billion (PwC, 2015).

\section{Aviation Sector Growth}

The aviation and aerospace industry experienced impressive levels of growth throughout the past decade starting in the early 1900s. The Aerospace and Defense (A\&D) industry, comprised of aircraft manufacturing; engine and engine parts manufacturing; aircraft parts and auxiliary equipment manufacturing; guided missile and space vehicle manufacturing, etc., accounted for total global revenue of about $\$ 1.2$ trillion in 2013 ( $\mathrm{PwC}, 2015)$. The Americas represented the most substantial portion of this revenue, computing nearly 50\%. In these two continents, the United States, Canada, Brazil, and Mexico represented the largest shares respectively $(\mathrm{PwC}, 2015)$. Although the most lucrative sector of the entire $A \& D$ industry is represented by the defense sector, countries like Mexico are experiencing astonishing growths within the civil aerospace segment. Over $65 \%$ of the total market value of the Mexican A\&D industry belongs to civil aerospace (PwC, 2015).

A considerable level of growth in sales has been experienced throughout global civil aerospace industries. From 2010-2014, the commercial aerospace industry nearly doubled, representing almost $\$ 300$ billion by the end of 2014 . Given that almost $90 \%$ of global commercial aerospace production is controlled by the United States and Europe, it can be assumed that entry and competition in this market are challenging. Nonetheless, manufacturing markets have begun to move 
to countries like Mexico, regardless of U.S. and European control of component production centers (Aviation Week, 2015). These trends have led to considerable opportunities for Mexico to enter a complex manufacturing market.

Contrarily, nations like Brazil have been involved in the commercial aerospace industry for many years and have proven to be highly experienced in the market. Brazilian flagship aerospace manufacturer Embraer is the world's largest manufacturer of commercial jet aircraft up to 130 seats and logged net revenues of nearly $\$ 14$ billion in 2013. Further evidence of Embraer's success can be observed via record-breaking backlogs for the company, reaching totals of $\$ 22$ billion that same year (Mann, 2014). These growth figures have remained stable as current backlogs today reach $\$ 25$ billion, delivering around $\$ 6$ billion annually and a total backlog of approximately 400 aircraft (Lourencao, 2016). However, as Embraer became an impressive international aerospace company, other aviation manufacturing efforts in Brazil receded. Other than companies that are directly linked to Embraer, there are relatively few operations across the country. Helibras, a subsidiary of Eurocopter, is a helicopter manufacturer in the region; however, it has only delivered about 500 units in total, roughly one unit per month since 1978 (ITA, n.d.). Due to this absence of growth among other aviation manufacturers in Brazil, Embraer holds crucial importance in market trends within its own country's borders and abroad.

According to Francisco Lyra, a partner at C>FLY Aviation in São Paulo, corporate aviation industries in Brazil share a predictive trend about the general economic standpoint throughout the country. The corporate aviation industry is represented by about four times the annual growth in GDP. Meanwhile, Brazil is a nation that only transports about half its total population via aviation annually. In comparison to the United States, Canada, and Australia, which on average transport about two to three times their population annually, the Brazilian aviation industry holds impressive potential for growth (Lyra, 2016). To take advantage of the industry, the Brazilian manufacturing and transportation sectors must come to terms with the sole potential for growth that lies within its borders.

Drastic improvements in overall operating efficiency are evident in advanced avionics, noise reduction capabilities, and innovative interior cabin designs. These have led to increased customer demand across the globe. The wider usage of composites, advanced manufacturing technology requirements and conversions into newer electrical systems have sizably changed the aircraft that are manufactured today. As a result, they have created overwhelming challenges throughout the global supply chain as supply bases struggle to make essential changes to keep up with aircraft original equipment manufacturer (OEM) demands. 
As the global aircraft fleet begins to age rapidly, the demand for these new advanced aircraft is expected to rise as well. Over the next 20 years, it has been estimated that approximately half of all new aircraft deliveries will by solely for replacements purposes (Gates, 2016). Impressive figures such as these prove the potential for high levels of international growth.

The world transport growth levels are closely correlated to the global economy. In general, air traffic varied from one region to the next. Development has been expected across many emerging markets that are supported by strong economic growth, high levels of urbanization, and expanded middle-classes. A vital spark for growth has been identified in developing economies via the liberalization of foreign trade policies through continuous barrier-breaking (Taylor, 2015). Additionally, the growth in demand for aircraft entails an overwhelming demand for financing. In 2013, the new aircraft market was estimated to be well over \$100 billion and supported by banks, capital markets, lessors, export credit agencies (ECAs) and an array of other financial institutions. The overall availability of financing under banks, capital markets, lessors, and ECAs are subjective to typical market fluctuations. Most aircraft manufacturers undertake long-term methods of planning to manage production, which triggers unfavorable effects on the liquidity when facing short-term variations in the market. Without the support of these financial institutions, most importantly ECAs, the market lacks stability, as was the case during more recent global financial crises (Taylor, 2015). For these reasons, global and local economies play a highly influential role in the growth of the aerospace sector. Global air traffic should continue to expand, resulting in the demand for new aircraft, which in turn demand the necessary financial support to sustain growth.

\section{Current Economic Trends in Aviation}

Throughout the Latin American and Caribbean (LAC) region, Brazil and Mexico represent the two largest economies. The past few years have proven troublesome for Brazil as the country slipped into recession due to an array of global and domestic challenges. Mexico, on the other hand, is still experiencing positive growth, although its economy undoubtedly slowed following recent economic crises (World Bank, 2016). Even before recent economic crises, Brazil had an unstable economic recovery initially triggered when the Brazilian Central Bank delinked the Brazilian real from the United States Dollar in 1999 (Regani, 2007). Regardless, current GDP growth percentages convey the reality of economic 
trends throughout the LAC region, more specifically Brazil, which is lagging all LAC economies (see Figure 1).

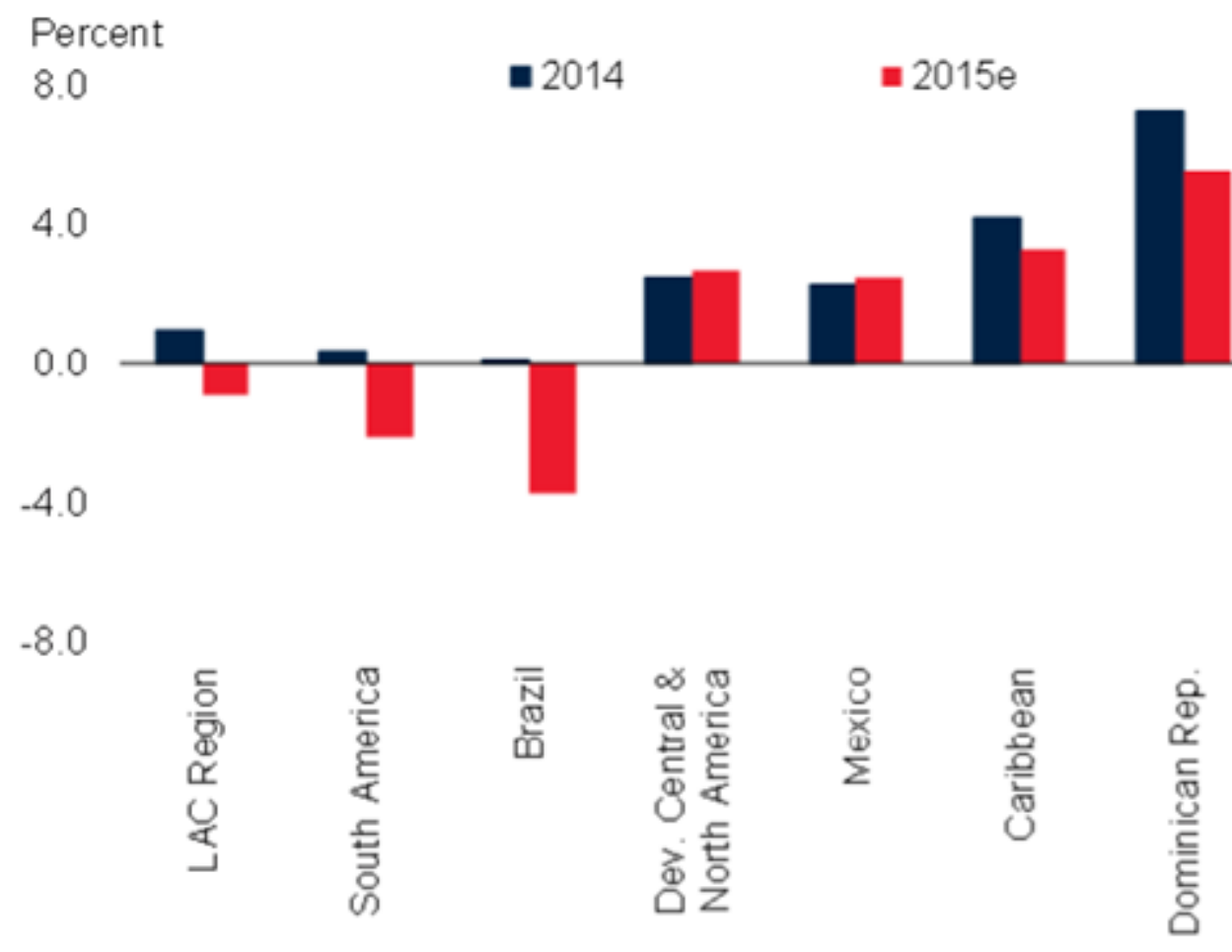

Figure 1. Regional GDP contracted in 2015 (World Bank, 2016).

Note: $\mathrm{e}=$ estimated GDP averages

According to the World Bank, Brazil experienced low-level recovery growth rates in the past three years. In 2013, the country met a three percent growth rate from the prior year, whereas, in 2014, faced only one-tenth of a percentage of growth from 2013. Worse off, GDP contracted nearly four percent in 2015. Furthermore, this downward trend diminishes slowly with forecasted growth to reach $1.5 \%$ by 2018 , but with uncertainties and volatility in the country, this forecast is unreliable. To the contrary, Mexican GDP growth shows a consistent upward trend from 1.4\% in 2013 to a forecasted 3.2\% by 2018 (World Bank, 2016).

All trends considered, the LAC region experienced contractions throughout 2015. The result of three consecutive years of slowed growth has led to output levels in the region to drop by almost one percent in 2015. Undoubtedly, this leads to sharp declines in the overall economic activity of many large regional economies like Brazil. The issue at hand for the Brazilian economy is not only a shrinking 
GDP but also widening deficits by more than a percentage point from less favorable starting positions. Additionally, Brazilian debt rose above $50 \%$ of its estimated GDP in 2015. Any further depreciation in the country's fiscal sustainability could eventually result in weakened investor response. As gross capital flows appear concerning, sharp slowdowns in 2014 led to shrinkage across the region. Figures for 2015 are estimated to have depreciated by $40 \%$ from the prior year (World Bank, 2016). These weaker than expected growth tendencies raise concern in the region especially considering increased political uncertainty in countries like Brazil.

Growth slowdowns can often reduce total portfolio investment as well as foreign direct investment (FDI) outflows to other countries. Many business operations are concerned that reduced financial flows could further set back investment growth, specifically long-term in many destination countries. Most concerning is the low and lower-middle income countries that frequently rely on payment inflows, as they are more vulnerable to international turbulences across foreign labor markets. Although this may suggest greater spillovers between countries with more significant related financial flows, the opposite may also be possible should there be an incentive to diversify risk internationally. For example, if a specific investor is concerned about growth setbacks in one nation, the investor may choose to increase investment with other nations that have better growth projections (World Bank, 2016). The result would lead to capital flowing out of one nation and into another nation that boasts better projections. This may be the case in Brazil. Brazil is a nation that does not have much competition in aviation manufacturing markets, therefore discouraging foreign investment from entering these problematic local markets.

Consumer price inflation is also an obstacle for the Brazilian economy, which reached a 12-year high throughout the last two quarters of 2015. Much of the change was due to higher underlying inflation with core inflation rates rising to nearly ten percent, as well as, the one-off effect of a reduction in subsidies and an increase in administered prices. These trends led the Banco do Brazil to raise policy interest rates to $14.25 \%$ (World Bank, 2016). Countries like Mexico experienced the opposite (see Figure 2).

Despite seeing $12 \%$ depreciation of the Mexican Peso, as compared to the United States Dollar, Mexican consumer price inflation reached a historic low in 2015. Low consumer price inflation enabled the Banco de México to maintain an incredibly low-interest rate of three percent for the majority of 2015. Regardless of Mexico's suffering from lower oil revenues, strengthening the export performance of manufacturers within the country represented a much larger share of Mexican trade, in turn benefiting from the weak peso (World Bank, 2016). 


\section{A. Reglonal consumer price inflation}

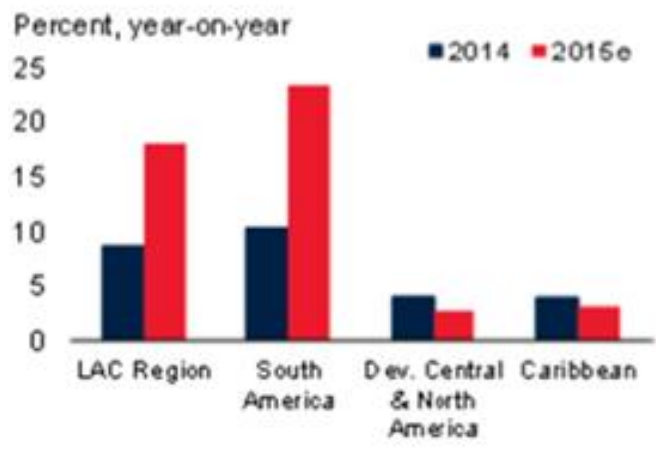

B. Headline and core Inflation, selected countries, 2015

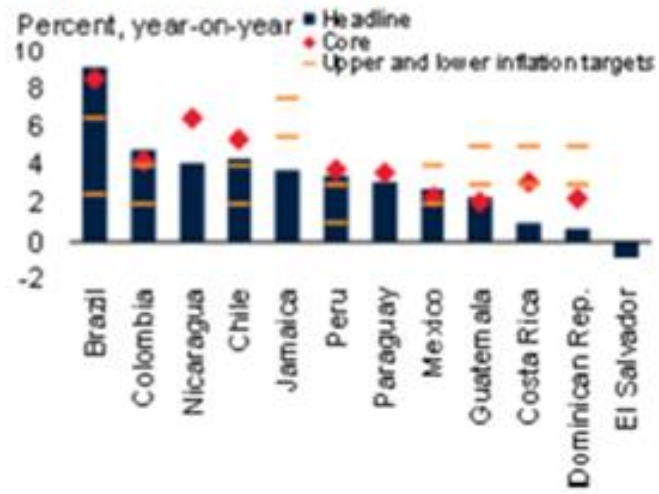

Figure 2. Inflation rates divergence.

Note: e = estimated; A. GDP averages; B. year to date November or October 2015 (World Bank, 2016).

Mexico was not the only nation that experienced growth in export markets. South American exports expanded roughly five percent in 2015, which was led by none other than Brazil, with a significantly depreciated real. Furthermore, North and Central American exports with close ties to the United States grew nearly ten percent throughout the same year (World Bank, 2016, p. 103). These North and Central American nations benefit highly from close economic ties with the United States economy and therefore have projected future growth levels of over three percent in 2016 and increasing annually. Mexico, although anchored by reduced government borrowing, benefited from the weaker peso. Linkages enhanced by the North American Free Trade Agreement (NAFTA) routed 80\% of Mexico's exports to the United States, thereby providing a highly competitive boost to the country's export-based manufacturing sector (World Bank, 2016, p. 106 \& 113).

In retrospect, the United States dollar holds significant importance regarding the consideration of the aerospace general outlook. The U.S. dollar experienced an average of about a $20 \%$ increase against other currencies, of which are major trading partners of the United States since 2014, rising more than 50\% against emerging-market currencies like Russia and more importantly, Brazil (Gates, 2016) (see Figure 3). This recent value growth of the United States dollar will continue to create an array of challenges for non-U.S. competitors. Even the smallest of changes can hinder demand in these markets; especially those who generate sales in local currencies, yet purchase aircraft in the United States dollar. 
A. Exchange rates against U.S. dollar

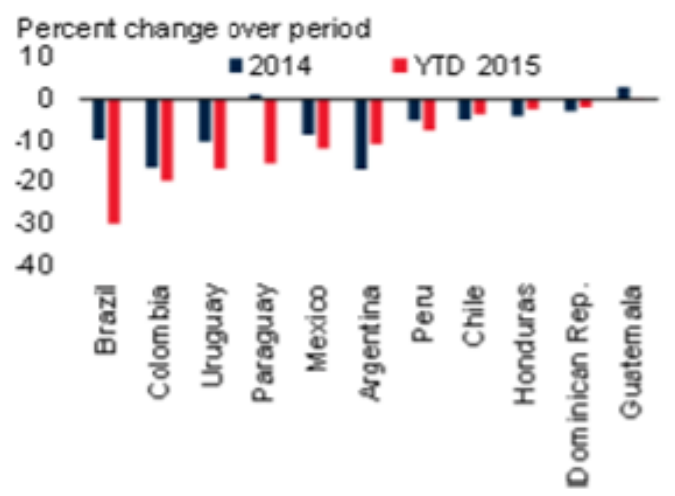

B. Real effectlve exchange rates

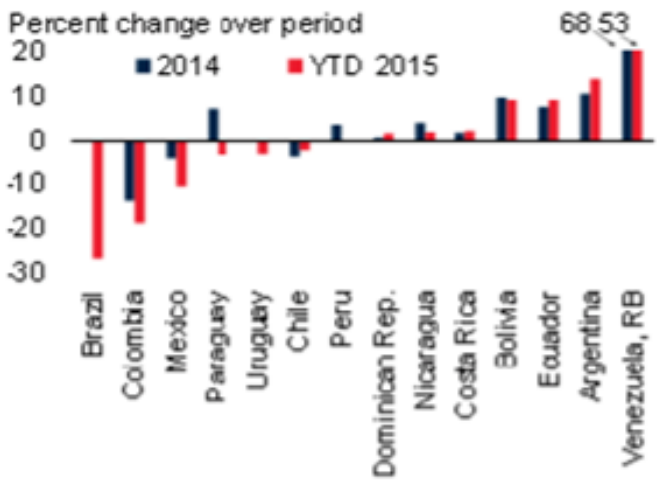

Figure 3. Exchange rates and real effective exchange rates.

Note: A. Up to November 2015 B. Up to September 2015; increase denotes real appreciation (World Bank, 2016).

\section{Manufacturing Trends in Brazil}

It is generalized that aerospace manufacturing trends in Brazil closely relate to economic patterns within the country; however, this is not always the case. If Brazil had a more competitive aerospace industry, this relationship would have likely existed. Instead, the Brazilian aerospace manufacturing sector is almost entirely based upon Embraer. The manufacturer owns roughly $90 \%$ of the local Brazilian market (Utsumi, 2014). However, this only represents a small fraction of the business in which Embraer participates outside of Brazil. Therefore, what regulates, Embraer's activities are the necessities and demands of the global aerospace industry because it produces more aircraft to be sold abroad than at home (Villas-Bôas, 2016). North American markets explicitly account for more than 50\% of all Embraer deliveries, whereas, European, African, Middle Eastern, Asian and Latin American markets together account for another 35\% of Embraer deliveries (Lourencao, 2016; Mann, 2014). The manufacturer claims not to be a Brazilian company, but rather an international company headquartered in Brazil. Although Brazil is home to the company's two largest manufacturing plants in São José dos Campos and Botucatu, Embraer now has production centers in Florida, China, Spain, and Portugal with hopes to enter the market in Singapore soon. The company's shares are divided nearly in half with $48 \%$ represented in the BM\&F Bovespa Stock Exchange in São Paulo and 52\% on the New York Stock Exchange. Furthermore, the company's budget is based on the United States dollar, which centers a significant linkage to the promising U.S. economy. For these reasons, economic issues in Brazil rarely affect Embraer's commercial aircraft production, 
unless significant fluctuations in the Brazilian real occur, which may lead to downgrade investment (Lourencao, 2016).

Defense and security manufacturing sectors within Embraer carry a more vulnerable position about the Brazilian economy. These manufacturing efforts are entirely contracted by the federal government on a Brazilian real budget. Many parts and components for military aircraft are purchased from the United States in U.S. dollars, therefore, leading to massive budgeting issues within these contracts. Also vulnerable to failure are the efforts of new entrant manufacturers in Brazil. Embraer's massive size often trumps smaller manufacturing efforts that are closely tied to the Brazilian economy. More so, the aerospace manufacturing industry is commonly difficult, as it requires high levels of globalization and connectivity to sufficiently profit given small sums of overall units produced annually (Lourencao, 2016). Without significant government support and intervention, it is unlikely the aviation manufacturing industry in Brazil will expand.

To stimulate industry growth, the Brazilian government proposed an industrial plan known as Brasil Maior (Bigger Brazil) aimed at creating favorable tax benefits for Brazilian manufacturers, which would reduce lending and energy cost via addressing fiscal, legal, financial and infrastructural obstacles throughout the country. However, despite the plan, Brazil's high corporate tax rates and labor cost hampered overall attractiveness for FDI and local competition (Deliotte, 2012). Without the proper existence of government incentives and a relatively unstable Brazilian economy, it is difficult to rely on development banking to cultivate the aerospace sector within the country (Villas-Bôas, 2016).

As a nation that is struggling to supply jobs for many of its citizens, financial and governmental concerns place a heavy burden on Brazil. Unlike the United States, which provides many opportunities for aviation industry careers like Boeing, Lockheed Martin, General Electric, and Rolls-Royce, Brazil does not offer as many opportunities for the aviation workforce. Furthermore, as the Brazilian national education system struggles, less fortunate families often lack access to adequate schooling required for a technical manufacturing career. For these reasons, Embraer found importance in social responsibility to promote the growth of an educated workforce. The company opened a schooling center known as the Embraer Institute of Education and Research, aiming to provide higher-level education to children of low-income families. However, this institution accepts less than fifty students annually (Lourencao, 2016). Small acceptance numbers as these are unlikely to resolve educational and workforce concerns throughout the country. Overall, the nation is experiencing a less qualified workforce resulting in a general disinterest in the field. However, the Brazilian National Bank for Economic and Social 
Development (BNDES) believes that industry could employ roughly 80,000 skilled employees by 2020, although current numbers are less than half of this figure (Utsumi, 2014). According to Embraer, their Brazilian manufacturing plants employ over 12,000 skilled personnel, consisting of approximately 5,000 engineers and 10,000 technicians who work on the process design, manufacturing processes and so on. The manufacturer hires new personnel regularly, however in small numbers. During a hiring window last year, Embraer was seeking 40 positions within the company for which they received over 5,300 applicants (Lourencao, 2016). Many would speculate that this is due to the likeability of the manufacturer as one of the best companies to work for in Brazil, or perhaps the Brazilian industry lacks other opportunities.

Although Brazilian aerospace exportation has been responsible for revenues around six billion real, the estimated cost of imports has been much larger than that of exports. Brazil imported the largest amount of parts and portions from other countries like the China, Europe, and the United States (Utsumi, 2014). Although Brazil has been a major supplier to the United States' market, the country competed for more in sales of final aircraft than parts and components. In 2008, Brazil imported a massive $\$ 5.75$ billion worth of aerospace products from the United States of which roughly $\$ 2$ billion was complete aircraft and the remaining $\$ 3.7$ billion was parts and components (ITA, n.d.) (see Figure 4).

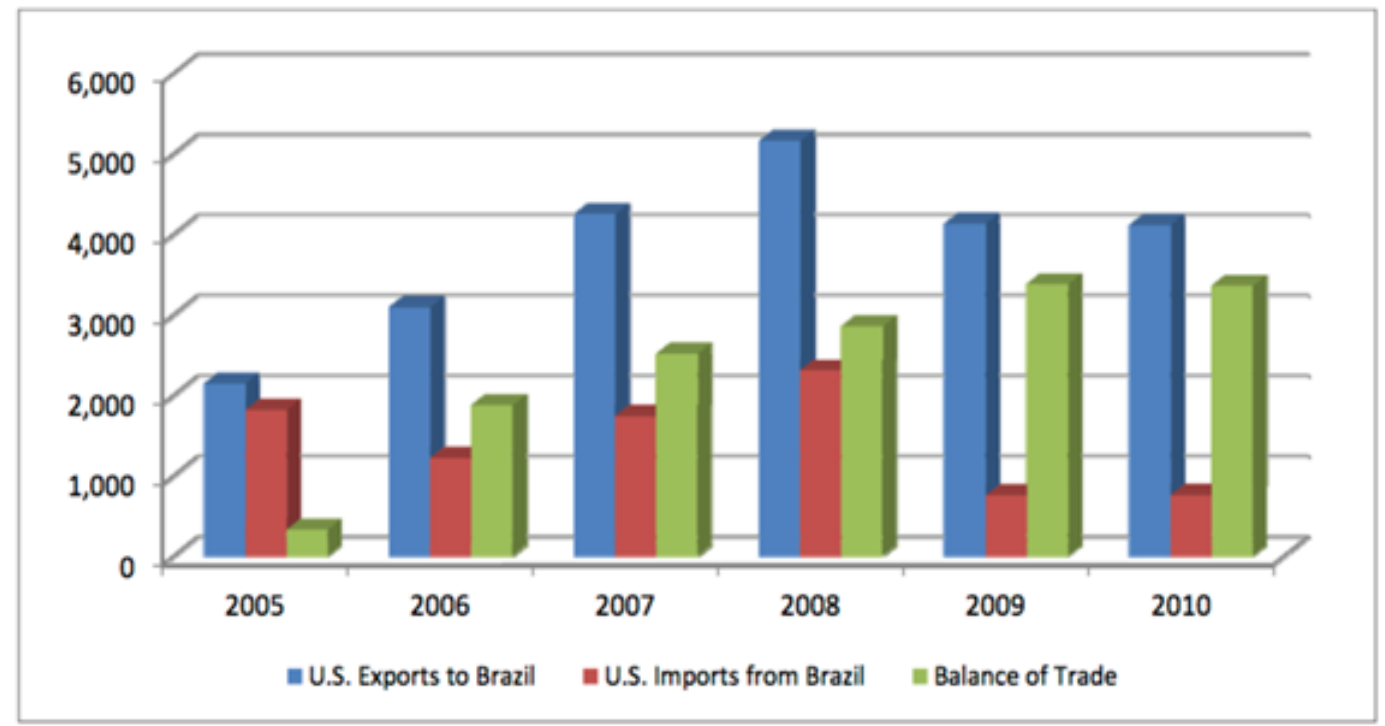

Figure 4. U.S. aerospace trade with Brazil in millions of dollars.

Note: From ITA, n.d. 
Even if Brazil desired to expand manufacturing jobs domestically, it is evident employing the workforce would be too costly, as labor is heavily taxed through various employment taxes and entitlements required by federal law that often exceed $100 \%$ of an employee's salary. On average, Brazilian engineers earn a starting salary of 70,000 real annually, translating to costs upwards of 150,000 real per employee for a Brazilian company (Villas-Bôas, 2016). These costs often outweigh the benefits of regenerating Brazilian manufacturing efforts.

\section{Manufacturing Trends in Mexico}

Manufacturing trends are remarkably robust as the country mushroomed into the 13th largest economy in the world, in nominal terms, and sits at the $11^{\text {th }}$ highest nation in purchasing power for the past three years (Mecham, 2013). As of 2013, Mexico boasted roughly 270 different aerospace companies of which nearly $80 \%$ are in the manufacturing sector, five times what existed in Mexico ten years prior (see Figure 5). Mexico, a nation of approximately 115 million people, half that of Brazil, aggressively began to develop stable careers paths as part of its expanding industrial basis beyond the automotive and electronics industries. Furthermore, current World Bank reports find that Mexican industrial products account for $90 \%$ of all export earnings (Mecham, 2013). Such improvements are leading "Hecho en Mexico" (Made in Mexico) to be increasingly common on all fronts, especially aerospace.

As Mexican aerospace exportation nearly doubled from 2010-2014, these exportation values reached over $\$ 1.1$ billion, while experiencing a trade balance of approximately $\$ 650$ million in 2014 (PwC, 2015) (see Figure 6). Undeniably, much of this growth is influenced by attractive low-wage structures in Mexico. It has been proclaimed that Mexican manufacturers pay a tenth of what equivalent assembly positions cost in the United States. Others claim it to be the difference of about a third from what is often paid in Europe. Nonetheless, such pay structures allow space for considerable profits in the process (Mecham, 2013). Regardless of low pay scales as compared internationally, the number of employees working in the Mexican aerospace industry increased drastically from roughly 11,000 in 2010 to nearly 22,000 in 2014 because of the high desirability of these occupations across the Mexican employment markets ( $\mathrm{PwC}, 2015)$. These workforce growth rates are the result of many technological institutions and research centers across the country, which promote the need for skilled personnel in the aerospace sectors. Among these centers are: Centro de Ingeniería y Desarrollo Industrial (CIDESI), Centro de Investigación y Desarrollo Technológico en Electroquímica, S.C. (CIDETEQ), Centro Nacional de Metrología (CENAM) and many more. These institutions all have coverage over the aerospace clusters, expanding technology and testing spaces 
that provide technical services, infrastructure, equipment technology and technical/administrative support (PwC, 2015). Incredibly, these schools and universities have been offering programs to educate technicians and engineers since 1937. Furthermore, schools are highly developed covering core courses, high school, technical degrees, professional licenses, engineering degrees and even some master's programs (PwC, 2015). Establishments like these create a highly capable workforce that seems to show record-breaking levels of growth throughout the recent years, perhaps due to surrounding global interests.

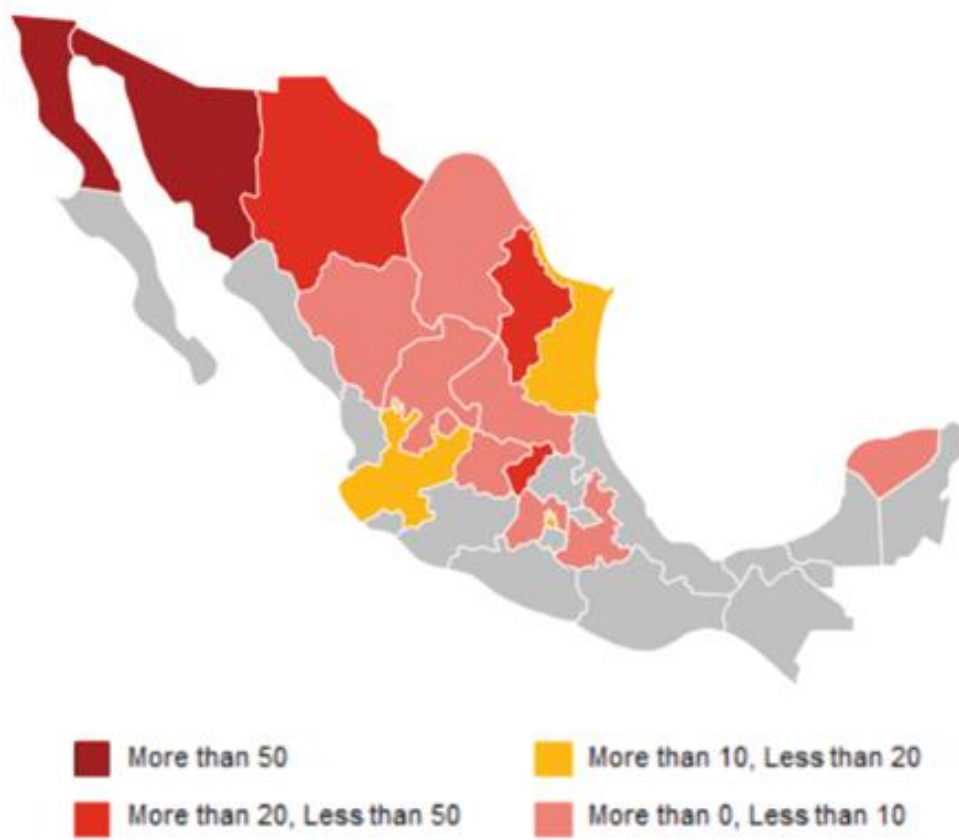

Figure 5. Number of companies in Mexican states A\&D industry in 2014. Note: From PwC, 2015.

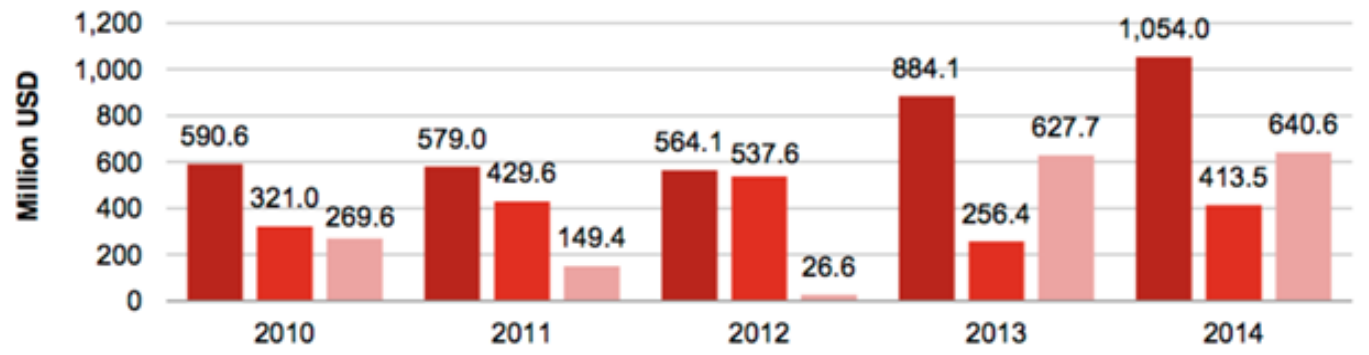

Figure 6. Mexican aerospace trade balance, millions of US dollars, 2010-2014. Note: From PwC, 2015. 
In the past 15 years, Mexico experienced over $\$ 3.2$ billion in foreign direct investment (FDI) of which the United States and Canada together have represented over half of the total influx. Other countries like Spain, Luxemburg, and France have also displayed considerable interest via foreign direct investment (FDI). In total, $54 \%$ of all the FDI in the Mexican aerospace industry went to manufacturing efforts of civil and business aircraft, followed by the manufacturing of other aerospace components (PwC, 2015). Behind most of this FDI is what Mexico refers to as the Maquiladora factory system, which allows foreign companies to control the entire manufacturing process by importing raw materials and then exporting the finished product tax-free. Furthermore, resident foreign companies can control $100 \%$ of their businesses, not having to face local partner rules that are highly common everywhere else and often limit foreign companies to a maximum $49 \%$ share (PwC, 2015). According to Eurocopter, a French-German company, Mexico is a prized sales territory. President/CEO of the company, Lutz Bertling, claims, "It is the most promising economy in the region, better than Brazil." The company recently opened a $\$ 100$ million factory in early 2013, finding interest in growth markets in 'New World' sales," (Mecham, 2013). Even more appealing is Mexico's free trade networks that are perhaps the most extensive across the globe. The country currently holds upwards of 40 treaties with other nations, most of which were kick-started after the signing of NAFTA, as well as the Asian-Pacific Economic Cooperation (APEC), the Trans-Pacific Partnership Agreement (TPP), and many more (World Bank, 2016).

Overall, the Mexican government made essential steps to secure a healthy aerospace industry not only through appealing opportunities for foreign nations, but also via strong controlling institutions in charge of regulating, promoting, and establishing the industry to consistently higher levels of performance over the past five years. Among these institutions are the Mexican Council of Aerospace Education (COMEA), the Agencia Espacial Mexicana (AEM), and the Federación Mexicana de la Industria Aeroespacial (FEMIA) (PwC, 2015). Even government banking cooperated in the ongoing development of the aviation sector to meet growth targets. Mexico's state development bank Bancomext plans to be a significant part of the aerospace expansion via an array of financing programs to aid in further growth and development. This program is similar to what is already offered by Mexican organization ProAuto, a joint project of banks and federal government agencies that provide credit options to domestic automotive part firms (Carbajal, Arellano, \& Valadez, 2015). Together, these massive group efforts are exceedingly stimulating the industry, economy, and country as a whole.

As parts manufacturing continues to experience high levels of growth in the region, aerospace industries across the globe are becoming more interested in 
manufacturing the entire product within Mexican borders. United States aircraft manufacturer Spectrum Aeronautical announced recently that it plans to invest approximately $\$ 300$ million in Mexican interests to build a factory that will manufacture one of its executive jets, becoming the first airplane to be entirely built in Mexico (Carbajal, Arellano, \& Valadez, 2015). Another aviation company becoming involved in Mexican industry is the Canadian aircraft manufacturer, Bombardier. As one of the larger aircraft manufacturers across the globe, Bombardier plans to eventually assemble complete aircraft in Mexico. Bombardier currently has an array of aircraft parts and even entire airplane sections manufactured in the Mexican city of Querétaro (Hawley, 2008). Among the items manufactured for Bombardier include wire harnesses that used to be manufactured in Kansas, rudders that used to come from Japan, tail sections that used to be done in Toronto and entire fuselages that were originally manufactured in plants from Northern Ireland (Hawley, 2008). Today, all these components are manufactured in a single city inside Mexico. Among other aircraft companies that manufacture in Mexico are Aernnova, a Spanish company that manufactures wings, tails and other sections for Boeing, Airbus, and Embraer in the city of Querétaro. Also manufacturing in Mexico is Cessna Aircraft and Hawker Beechcraft that have moved subassembly work from Kansas to Chihuahua. Another company that is manufacturing in Mexico is Goodrich, a North Carolina based company that manufactures engine cowlings for the Boeing 787 Dreamliner in Mexicali (Hawley, 2008). Even Brazilian aircraft manufacturer, Embraer plans for a joint production center with Zodiac, a French equipment manufacturer, shortly (Saliba, 2013). These companies only represent a small number of the collaborative interests in Mexican manufacturing industries.

Mexico created a more than average desirability for foreign companies, yet questions about the quality of manufacturing work risking safety and product integrity remain. Wisely, Mexico found a method to assure such concerns were nonexistent because the country prepared an important agreement to pledge proper levels of safety and integrity. The Bilateral Air Safety Agreement (BASA) allows the Dirección General de Aeronáutica Civil (DGAC) to certify parts, components, aviation systems, and even a full aircraft, that are manufactured and assembled in Mexico and then exported to the other nations. Such certifications are according to all relevant regulations of that foreign nation, as well as international standards (PwC, 2015). Overall, an impressive solution for Mexico that boasts valiant and respected efforts to assure the highest level of quality and professionalism.

With all information considered, there is one last feature that makes Mexico such a desirable location for aerospace manufacturing, the United States. The country's geographic proximity to the largest aerospace market in the world 
influences every other aerospace manufacturing nation to consider relocating to Mexico. Regardless of the value of the Mexican peso, the currency is still pegged to the U.S. dollar and therefore pegged to the U.S. market, allowing foreign nations to operate in a low-wage environment with access to a market otherwise expensive to infiltrate (Mecham, 2013). Mexico set noteworthy goals for the coming future by identifying their importance in the global aerospace industry. By 2020, the young nation plans to be within the tenth largest suppliers in the aerospace industry, with over $\$ 12$ billion in exports annually, over 110,000 skilled workers in the industry, and reaching 50\% of local content in raw materials and products throughout the industry (PwC, 2015). These are ambitious goals that look highly attainable for a nation like Mexico.

\section{Conclusion}

Only a few years have passed since the Mexican aerospace industry was virtually nonexistent. What occurred is a remarkable accomplishment for a developing nation that still has its eyes set for the peak of the mountain. To say, however, that its feat is impossible to other nations in the field is incorrect. The problem Brazil faces is an overall lack of concern for the future of its aerospace industries. Current political and economic events seem to push the prospect of growing the aerospace market even farther into the future. It is unquestionably clear that there is incredible room for industrial growth within the large Brazilian nation, but should the country fail to focus on regenerating Brazilian aerospace markets, it will fall significantly behind new entrant nations like Mexico, and experienced ones like the United States. Manufacturers like Embraer will continue to produce and profit, but will not lift the weight of an entire nation's aerospace industry. If current trends throughout both these nations continue, it is clear that Mexico will become the aircraft-manufacturing hub of the world. 


\section{References}

AviationWeek. (2015, December 23). Supply chain research insights: Global aerospace industry size and growth. Aviation Week \& Space Technology. Retrieved from http://aviationweek.com/master-supply-chain/supply-chain-research-insightsglobal-aerospace-industry-size-and-growth

Carbajal, B., Arellano, S., \& Valdez, R. (2015, April 23). México espera ‘boom’ en el sector aeroespacial en 2020 [Mexico expects boom in the aerospace sector in 2020]. Milenio, Business. Retrieved from http://www.milenio.com/negocios/Bancomext_financiamiento_sector_aeroespaci al-industria_aeroespacial_Mexico_0_505149497.html

Deloitte. (2012). Competitive Brazil: Challenges and strategies for the manufacturing industry. Retrieved from http://deloitteoracle.com/uploads/stw_pdfcart/Brazil_Manu_20121398094278.pdf

Embraer S.A. (2012). The history of aircraft production in Brazil before Embraer. Retrieved from Embraer Historical Center website: http://www.centrohistoricoembraer.com.br/sites/iba/enUS/Sobre/Pages/default.aspx

Gates, D. (2016, April 8). 5 key trends impacting the aerospace sector and what they mean for growth. IndustryWeek. Retrieved from http://www.industryweek.com/supplier-relationships/5-key-trends-impactingaerospace-sector-and-what-they-mean-growth

Hawley, C. (2008, April 6). Aircraft makers flock to Mexico. USA Today. Retrieved from http://usatoday30.usatoday.com/money/industries/manufacturing/2008-04-06aerospace_N.htm

International Trade Administration. (n.d.). U.S. aerospace trade with Brazil in millions of dollars [Chart]. Retrieved from http://www.trade.gov/static/aero_rpt_flight_plan_2011_brazil.pdf

International Trade Administration: U.S. Department of Commerce. (n.d.). Country studies: Brazil. Retrieved from http://www.trade.gov/static/aero_rpt_flight_plan_2011_brazil.pdf

Lourencao, P. (2016, March 15). [Personal interview by the author]. 
Lyra, F. (2016, March 15). [Personal interview by the author].

Mann, J. A., Jr. (2014, November 2). Brazilian aircraft manufacturer Embraer oversees North America operations from Fort Lauderdale. Miami Herald, Business. Retrieved from http://www.miamiherald.com/news/business/bizmonday/article3526642.html

Mecham, M. (2013, April 1). Mexico's welcome mat attracts aerospace manufacturers. Aviation Week \& Space Technology. Retrieved from http://aviationweek.com/awin/mexico-s-welcome-mat-attracts-aerospacemanufacturers

PwC Mexico. (2015, May). Aerospace industry in Mexico. Retrieved from https://www.pwc.com/mx/es/knowledge-center/archivo/20150604-gx-publicationaerospace-industry.pdf

PwC Mexico. (2015, May). Mexican aerospace trade balance, million USD, 2010 - 2014 [Chart]. Retrieved from https://www.pwc.com/mx/es/knowledgecenter/archivo/20150604-gx-publication-aerospace-industry.pdf

PwC Mexico. (2015, May). Number of companies in each states in Mexico's A\&D industry, 2014 [Map]. Retrieved from https://www.pwc.com/mx/es/knowledgecenter/archivo/20150604-gx-publication-aerospace-industry.pdf

Regani, S. (2007). Embraer: The Brazilian aircraft manufacturer's turnaround and growth (Publication No. BSTR243).

Saliba, F. (2013, June 25). Mexico aims high with investment in burgeoning aviation industry. The Guardian. Retrieved from http://www.theguardian.com/world/2013/jun/25/mexico-aviation-supply-industrygrowth

Taylor, N. (2015). Foreign trade and the aircraft manufacturing industry. Global Policy. Retrieved from http://www.globalpolicyjournal.com/blog/25/02/2015/foreigntrade-and-aircraft-manufacturing-industry

Utsumi, I. (2014, April 10). Brazilian aerospace industry. The Brazil Business. Retrieved from http://thebrazilbusiness.com/article/brazilian-aerospace-industry

Villas-Bôas, P. C. R. (2016, March 18). [Personal interview by the author]. 
World Bank. (2016). Exchange rates [Chart; PDF]. Retrieved from http://dx.doi.org/10.1596/978-1-4648-0675-9

World Bank. (2016). GDP growth, 2014-2015 [Chart; PDF]. Retrieved from http://dx.doi.org/10.1596/978-1-4648-0675-9

World Bank. (2016). Inflation rates [Chart; PDF]. Retrieved from http://dx.doi.org/10.1596/978-1-4648-0675-9

World Bank Group. (2016, January). Global economic prospects: Spillovers amid weak growth [PDF]. http://dx.doi.org/10.1596/978-1-4648-0675-9 